\title{
Detachment Surface Morphology and Shortening Distribution in the Foreland Folds of Iraq
}

\author{
Nabeel K. Al-Azzawi Saddam E. Al-Khatony Mahmood A. Al-Sumaidaie \\ Department of Geology \\ Department of Geology \\ College of Science \\ College of Science \\ University of Mosul \\ University of Mosul \\ Department of Geology \\ College of Science \\ University of Mosul
}

(Received 14/1/2013, Accepted 1/9/2013)

\begin{abstract}
Determinations of detachment surface depth and amount of local shortening were carried out in the more specific location foreland folds of Iraq. Twenty one traverses of anticlinal structures which are normally distributed on the study area were used for this application.

Two types of deformation styles were found in the study area. They are thinskinned and thick-skinned tectonics. Depth of the detachment surface generally increases towards east with as abnormal case appeared in Aqra Anticline. Westerlythe depth becomes shallower depth from the south towards Dohuk Anticline and it returns to increase toward the north. In Ain Zala, Butma West, Dohuk and Dahqan Anticlines and some parts of Bekhair Anticline, thin-skinned style was indicated.

The shortening generally increases towards the north and northeast, with specific anomaly at Permam Dagh. It increases in the area after Permam Dagh to the north and northeast. However southeast of this area has low amount of shortening and the lowest appears in Qara chauq Anticline.

keywords:Detachment surface, Shortening, Thick-skinned, Thin-skinned, folds.

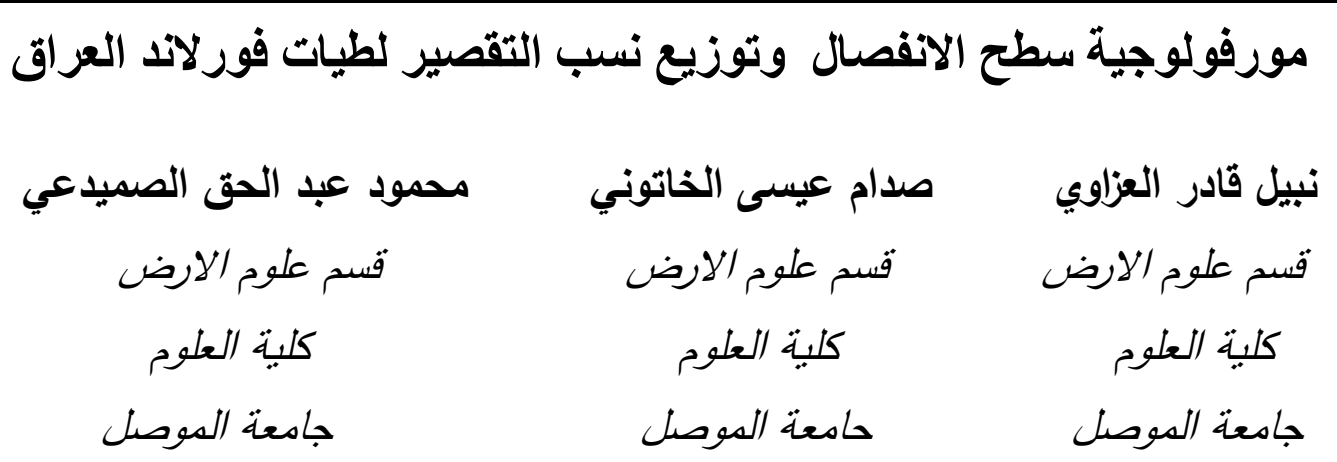




\begin{abstract}
الملخص
تضمن البحث دراسة 21 مقطع لـ 12 طية محدبة من طيات الحزام الفورلاندي في العراق موزعة

بشكل منظم لحساب عمق سطح الانفصال ومقدار التقصير الموضعي.

ظهر أن هناك نوعان من التشويه يسيطران على المنطقة وهما تكتونية الغطاء السميك وتكتونية الغطاء الرقيق. تبين ان سطح الانفصال بشكل عام يزداد باتجاه الثرق مع شذوذ في منطقة طية عقرة، ويتضحل غرباً الى طية دهوك ثم يعود ويزداد عمقا باتجاه الثمال. وتزداد نسبة التقصير الموضعي باتجاه الثمال والشمال الثرقي مع شذوذ في منطقة بيرمام داغ، ثم تستمر بالزيادة بعد هذه المنطقة باتجاه الشمال والشمال الثرقي ايضا في حين تقل باتجاه الجنوب منها، وان اقل قيمة لنسبة التقصير الموضعي تظهر في طية قره

الكلمات الدالة: سطح الانفصال، نسبة التقصير، الغطاء السميك، الغطاء الرقيق، الطيات.
\end{abstract}

\title{
INTRODUCTION
}

The foreland belt of Iraq is situated at the northeastern margin of Arabian plate. It is restricted by the latitude $\left(35^{\circ}, 45^{\prime}, 23^{\prime \prime}-37^{\circ}, 05^{\prime}, 11^{\prime \prime}\right)$ north and longitude ( $42^{\circ}, 28^{\prime}, 22^{\prime \prime}-44^{\circ}, 08^{\prime}, 53^{\prime \prime}$ ) east (Fig. 1). This belt comprises several folds and faults and called a "fold/fault belt". Folds in this belt have two trends, Zagros and Taurus. The first is oriented in a northwest-southeast direction whereas the second has eastwest direction. Moreover these folds have two types of vergence directions, some folds verging towards north or northeast, while other toward south or southwest.

Many methods have been used to calculate the amount of shortening in different deformed area, such as balancing cross section. Also many authors applied this method, such as (Bally et al. 1966); (Dahlstrom, 1969 and 1970) and (Elliot and Boyer, 1982) in Ramsay and (Huber, 1987) and (Suppe, 1985). (Billings, 1972) and (Ragan, 1985) suggested a method to measure shortening and depth of folding

According to the definition that a detachment is a surface separating folded and unfolded strata in a vertical section (Depth of fold), the present study has used a mathematical method suggested by Al-Azzawi (2008) to calculate the local shortening percentage of the foreland folds.This technique is capable of determining the depth of detachment surface by adding new factor (additional tectonic uplift). To calculate the local shortening for any fold, the total amount of mass uplifted (in Anticline) and subsiding mass (in syncline) are used (Fig. 2).

Twenty one traverses distributed in the foreland belt, were taken as samples for this analysis; these traverses taken across each of these foreland folds. Geological concepts using a series of appropriate mathematical equations are used by (Al-Azzawi, 2008). These equations which gave encouraging results for the detachment surface depth and shortening ratio are used in this work. 


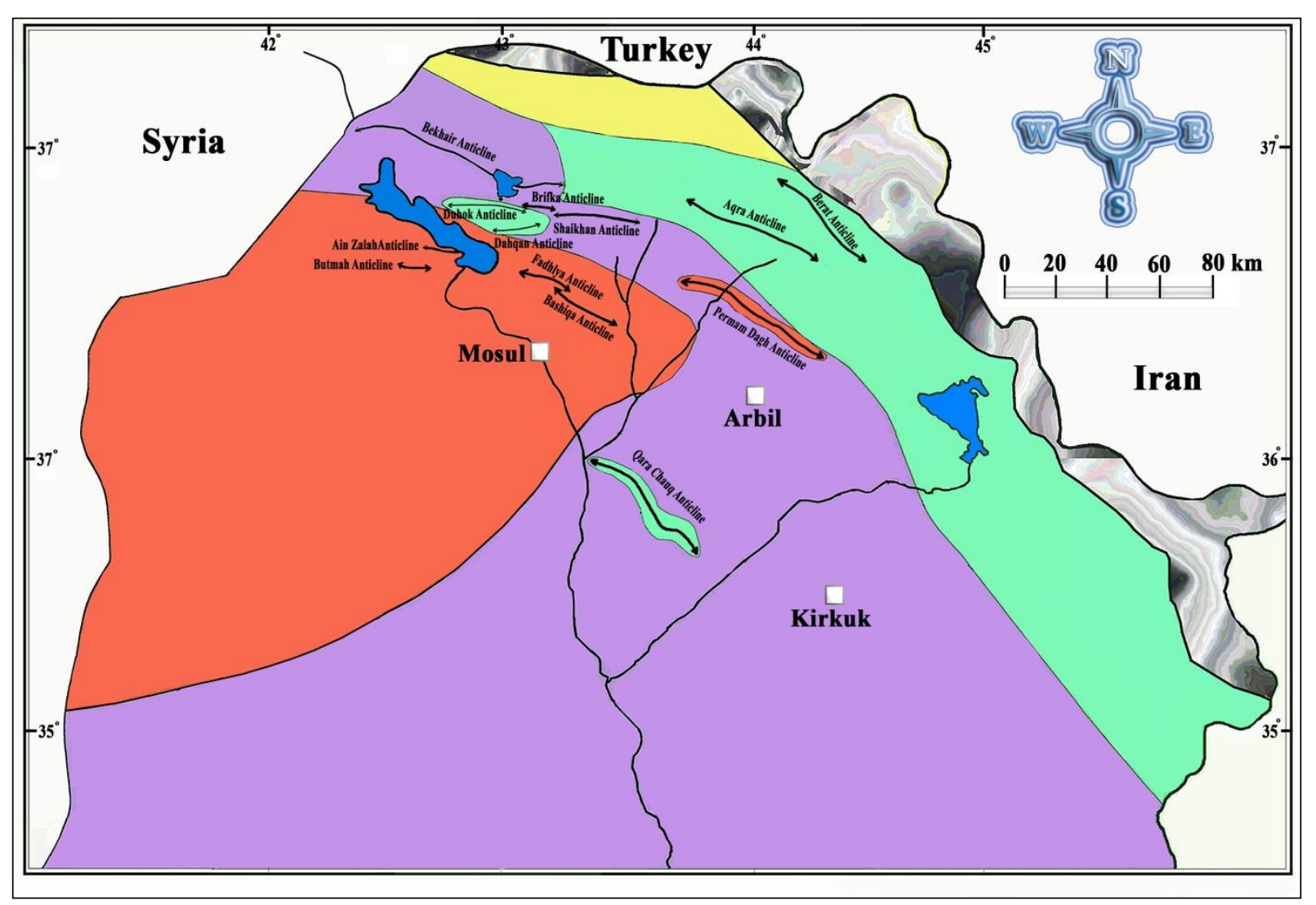

Fig. 1: Locations of the Studied Anticlines.

\section{PROCEDURES}

As it has been mentioned before, the present study used the method adopted by (Al-Azzawi, 2008). Which deal with the depth determination of the detachment surface and percentage of local shortening. For the application of this method, a set of procedures has to be followed. There are some assumptions which has to be taken into consideration, (Fig. 2). and the collecting data must be taken from the upper surface of Injana Fm.

- AF is the cross-sectional area before deformation.

- AB represents the cross-sectional area after deformation.

- AR refers to the cross-sectional area of uplifted mass only.

- Asr represent the area of structural relief.

- $\mathbf{h}$ is the depth of detachment surface.

- Ta represents the amount of tectonic uplift.

The following procedures are used to determine the local shortening and depth of detachment surface. Each anticline is analyzed as individual case (Fig. 2). 


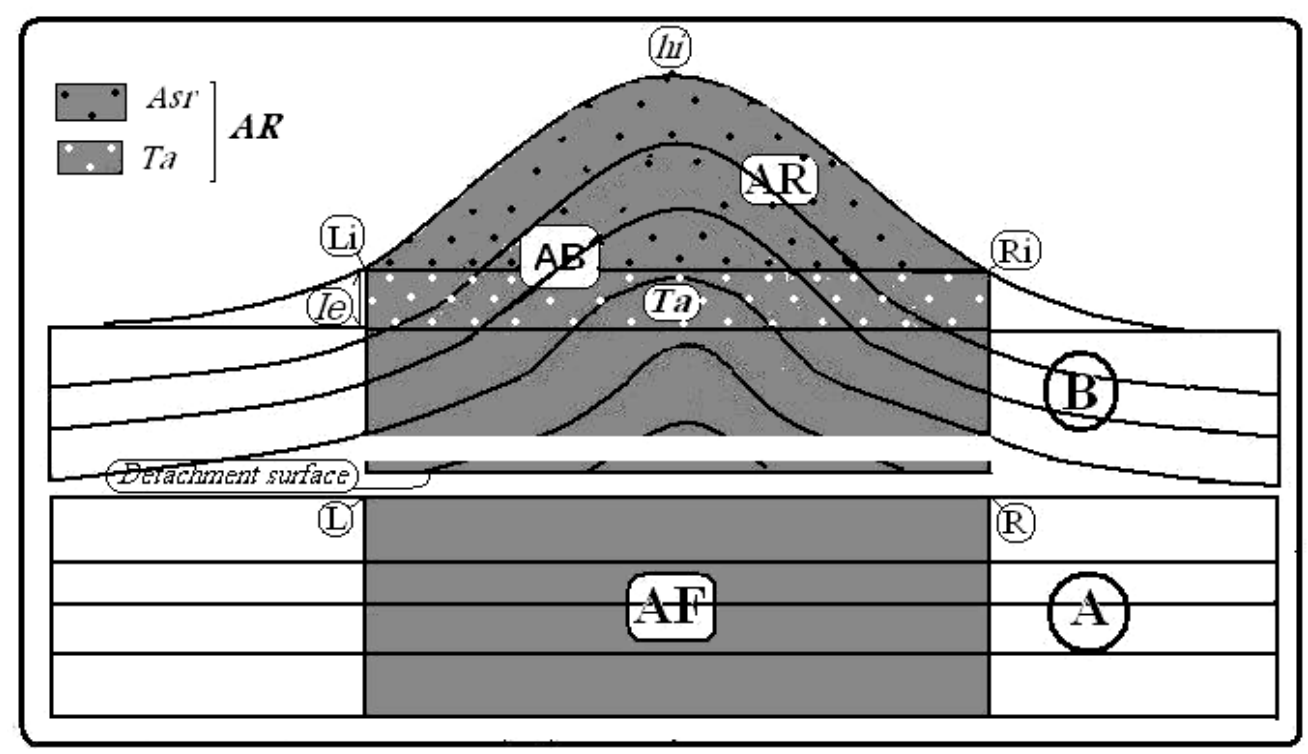

Fig. 2: The Shortening Idea (A) before and (B) after Tectonic Uplift (Al-Azzawi, 2008).

1- Construction of fold profile considering the upper surface of Injana Fm., as reference datum, using Busk method (Busk, 1929 in Huber and Ramsay, 1987).

2- Determination of Lo length which represent the horizontal distance between the two exposure points of Injana Fm. and Lc refers to the length of the curved line of structural profiles. Transformations of these values with respect to field scale are necessary. Then the difference between them is equal to the curvimetric shortening (Sc).

3- The present study uses a program (Advanced Grapher) in calculating the cross-sectional area. It shows an accurate result comparing with the integration or Planimeter methods.

4- Calculating the value of Asr taken into consideration the field scale. Asr area can be obtained either by Planimeter or by mathematical method, such as the integration method used by Al-Azzawi (2008).

5-Calculating the value of $\mathbf{h}$ (depth of the detachment surface) using the following expression: $\mathbf{h}=\mathbf{A s r} /(\mathbf{L c}-\mathbf{L o})$

6- Determination the value of AF: $\mathbf{A F}=\mathbf{L o . h}$

7- Then calculating the value of Ta which is the amount of tectonic uplift for a reference surface (the upper surface of the Injana Fm: Ta $=$ Ie. Lo

Where Ie represents the value of the height of the upper surface of the topographic of the Injana Fm.

8- Determination of $\mathbf{A R}$ from the following expression: $\mathbf{A R}=\mathbf{T a}+\mathbf{A s r}$

9- Consequently, determination of the percentage of local shortening from the following: Shorting $=($ AR.100 $) / A F$ 
The results of determination of the depth of detachment surface and the amount of local shortening are plotted on a map of foreland belt to illustrate the variations of each of the previous parameters with respect to space and depth. A computer program (Surfer 9) is used to represent data as contour maps and three dimension block diagrams. Each anticline location has the three geographical coordinate axes. The $\mathrm{X}$ and $\mathrm{Y}$-axes signify the latitude and longitude respectively, whereas Z-axis represents either the depth in the case of detachment surface or percentage ratio in local shortening.

\section{Shortening and Detachment Surface}

Seismic sections are the most proper way for studying the detachment surface, listric faults and other subsurface structures. But if these sections are not available then indirect method like the present one is useful. Hence it is applied to the following anticline samples using cross-sections. Some of these sections are taken from previous works and the others are prepared by the present authors. Brief descriptions for each anticline and their analyses were illustrated below.

\section{1-Bekhair Anticline:}

This anticline generally extends (71) Km towards northwest - southeast. It is one of the biggest anticline in the area. It has a triangular outline shape; its base is located at the southeastern plunge Besari / Zawita area and tapering towards the northwestern and ended with narrow plunge at Deraboon village near the IraqiSyrian-Turkish border (Alhubiti, 2008).

Bekhme Formation is the oldest (Late Cretaceous) represents the core of Bekhair Anticline. It followed by, Shiranish, Kolosh, Khurmala, Gercus, Avanah, Pila Spi, Fat'ha, and Injana Formation. These formations extends in time span from Upper Cretaceous to Late Miocene. Three traverses were taken across this anticline and structural profiles using top of Injana Fm. A reference datum has been constructed depending basically on sections of (Alhubiti, 2008).

Traverse (1) is located at the western part of the structure between Mergasore and Hettian villages. The analyses results are shown in (Fig. 3a). Where traverse (2) extends $8.5 \mathrm{Km}$ passing Bakose and Batas villages to the southeast of Zakho. Its results are illustrated in (Fig. 3b). And traverse (3) is situated between Barushki and Yekmalah at Spi Raise segment which represent the southeastern part of this anticline. Depth of detachment surface and the percentage of shortening are taken from (Al-Azzawi, 2008). 


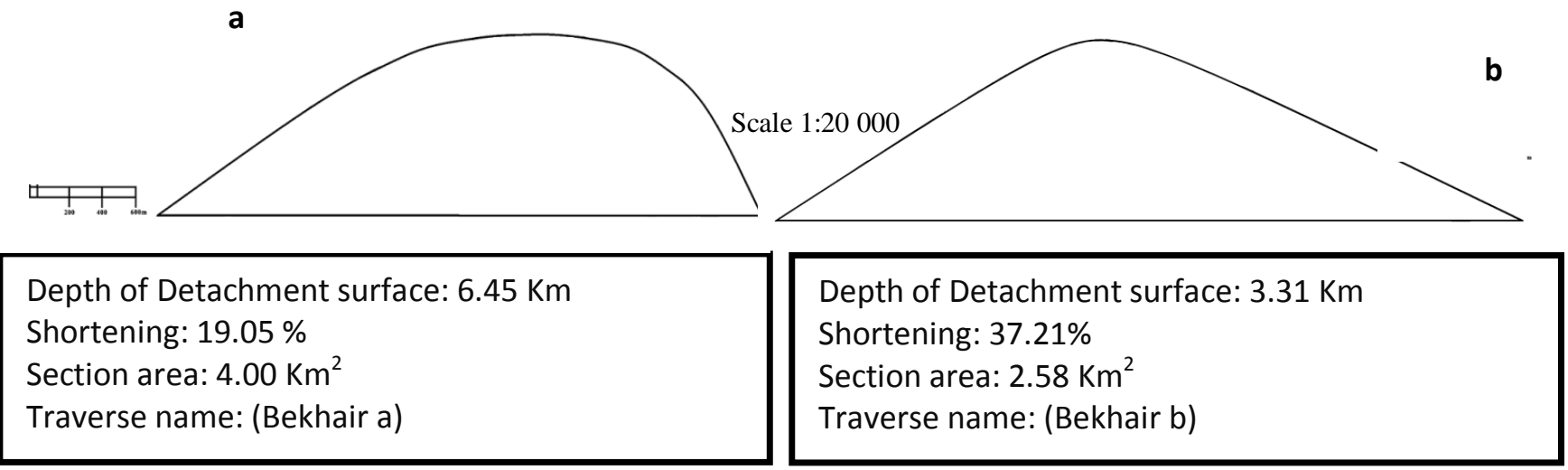

Fig. :3 a- Structural Profile for Traverse (1), b- Structural Profile for Traverse (2) of Bekhair Anticline

\section{2-Shaikhan Anticline:}

It is asymmetrical fold, verging towards the north, double plunging and generally extends $31 \mathrm{Km}$ east-west from Kavrasor to at Mamiz Dina villages. Bekhme is the oldest formation (Upper Cretaceous) and followed by the subsequent formations in descending time span to Late Miocene. They are Kolosh, Gercus, Pila Spi, Fat'ha and Injana (Al-khatony, 2009).

Two sections were considered from (Al-khatony, 2009) which are perpendicular to the fold axis. Analysis is taken place on section (1), which extends north-south from Khinis to Rigawah villages. Figure 4a, are showes the result of the analysis. While section (2) extends from gali Taricha at the north to gali lalesh in the south. Figure $4 \mathrm{~b}$, illustrates the shortening percentage and detachment surface depth.

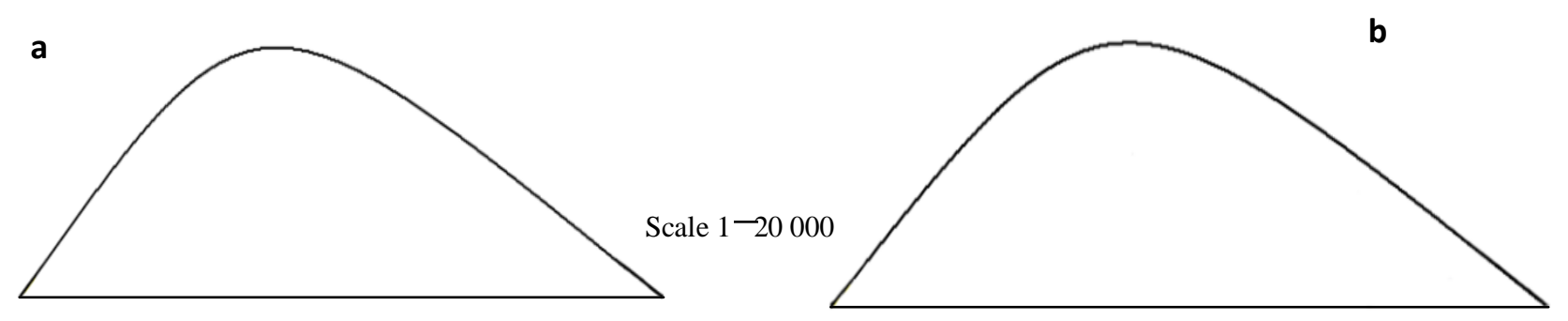

Depth of Detachment surface: $6.45 \mathrm{Km}$

Shortening: $18.91 \%$

Section area: $6.45 \mathrm{Km}^{2}$

Traverse name: (Shaikhan a)
Depth of Detachment surface: $7.72 \mathrm{Km}$

Shortening: $18.82 \%$

Section area: $10.2 \mathrm{Km}^{2}$

Traverse name: (Shaikhan b)

Fig. 4: a- Structural Profile for Section (1), b- Structural Profile for Section (2) of Shaikhan Anticline. 


\section{3-Aqra Anticline:}

Aqra Anticline is asymmetrical, double plunging and extends for $32 \mathrm{Km}$ from the Bigil at the east towards Backerman in the west. It is surrounded from the north by Nahla Valley and in the south by AshaerAlsab'a plain (Maroof, 1983). Three structural profiles were drawn based on three cross-sections taken from the same reference. Traverse (1) situated along Gali Zanta across the anticline and presentation of the result is shown by (Fig. 5a). The extension of traverse (2) is from Kundik at northern limb to Mast at the south. Determination result is displayed in (Fig. 5b). The area of the eastern plunged is represented by traverse

b (3) and its analysis is illustrated in (Fig. 5c).
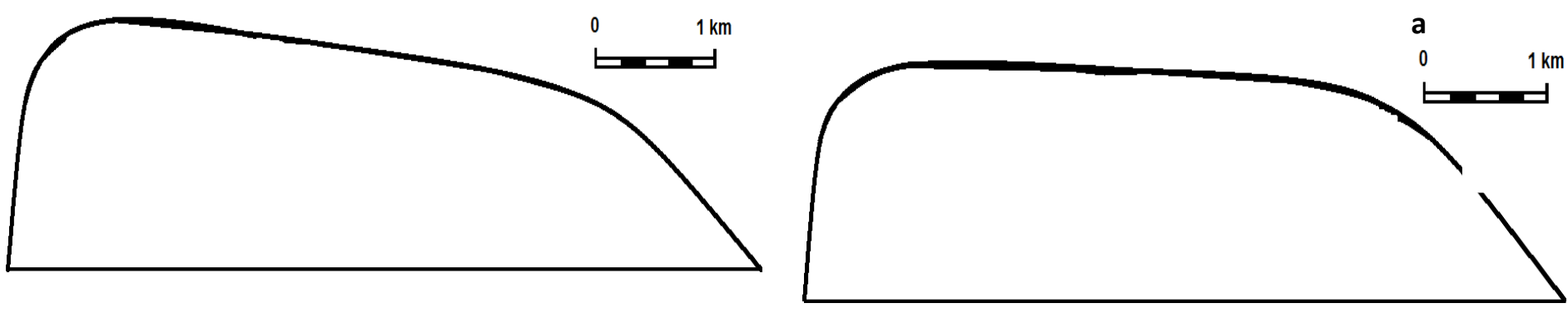

Depth of Detachment surface: $5.18 \mathrm{Km}$

Shortening: $36.08 \%$

Section area: $7.25 \mathrm{Km}^{2}$

Traverse name: (Aqra b)

Depth of Detachment surface: $6.06 \mathrm{Km}$

Shortening: $30.26 \%$

Section area: $7.16 \mathrm{Km}^{2}$

Traverse name: (Aqra a)

Fig. 5: a- Structural Profile for Traverse (1), b- Structural Profile for Traverse (2), of Aqra Anticline.

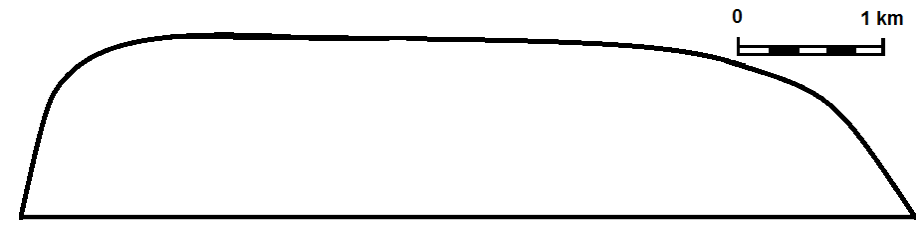

Depth of Detachment surface: $5.25 \mathrm{Km}$

Shortening: $33.32 \%$

Section area: $6.30 \mathrm{Km}^{2}$

Traverse name: (Aqra c)

Fig. 5: c- Structural Profile for Traverse (3) of Aqra Anticline. 


\section{4-Berat Anticline:}

It is convex asymmetric cylindrical fold, coaxial length is (35) $\mathrm{Km}$ and a width of (13) $\mathrm{Km}$. The Chia Gara oldest formation is exposed in the core of the anticline and followed by the formations of descending ages. They are Balambo, Qamchuqah, Bekhme, Shiranish, Tanjero, Kolosh, Gercus, Pila Spi, Fat'ha and Injana (Al- Hamdani, 1992). Two sections which constructed by the same reference, are used in this analysis. Figure $6,(a, b)$ represents the analysis output.
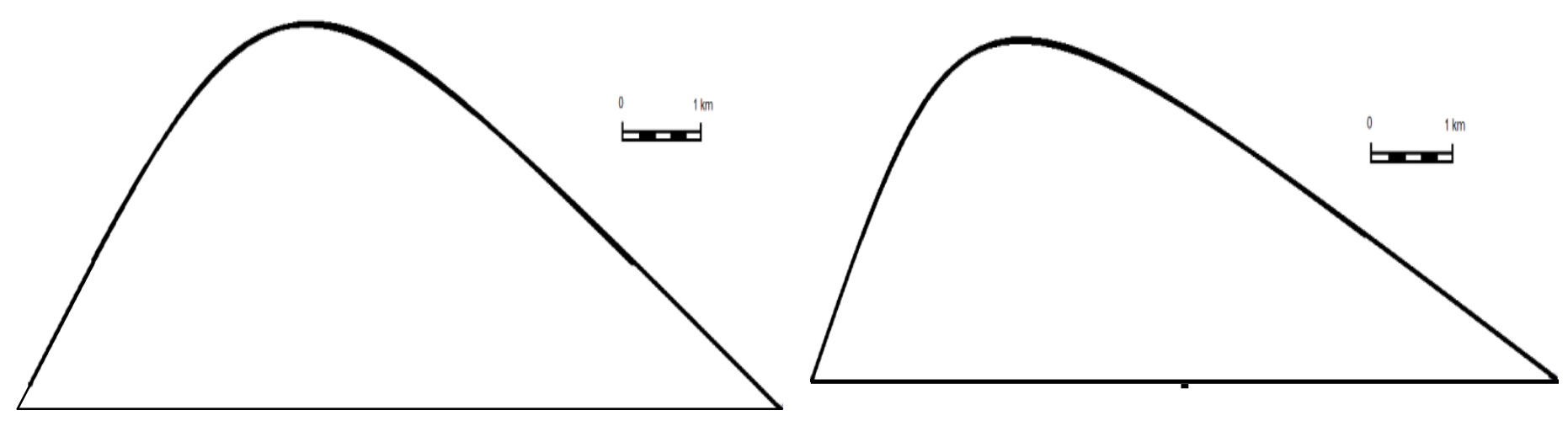

Depth of Detachment surface: $8.64 \mathrm{Km}$

Shortening: $25.85 \%$

Section area: $15.56 \mathrm{Km}^{2}$

Traverse name: (Berat b)

Depth of Detachment surface: $7.35 \mathrm{Km}$

Shortening: $27.41 \%$

Section area: $13.83 \mathrm{Km}^{2}$

Traverse name: (Berat a)

Fig. 6: a- Structural Profile for Traverse (1), b- Structural Profile for Traverse (2) of Berat Anticline.

\section{5-Dahqan Anticline:}

Dahqan is asymmetrical anticline, extends for $11 \mathrm{Km}$ in an east-west directory with, $(2$ - 4) Km width, double plunging and the oldest exposed formation is Pila Spi Fm. which plays as a carapace of the fold. This formation is followed by Fat'ha and Injana formations respectively (Al-Sammarrai, 1990). Two sections are taken across the anticline and the analysis output is displayed in, Fig. 7: $(a, b)$. 
b

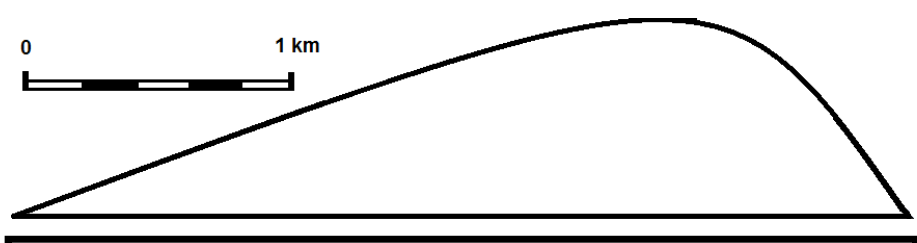

Depth of Detachment surface: $3.27 \mathrm{Km}$

Shortening: $29.64 \%$

Section area: $3.10 \mathrm{Km}^{2}$

Traverse name: (Dahqan b)

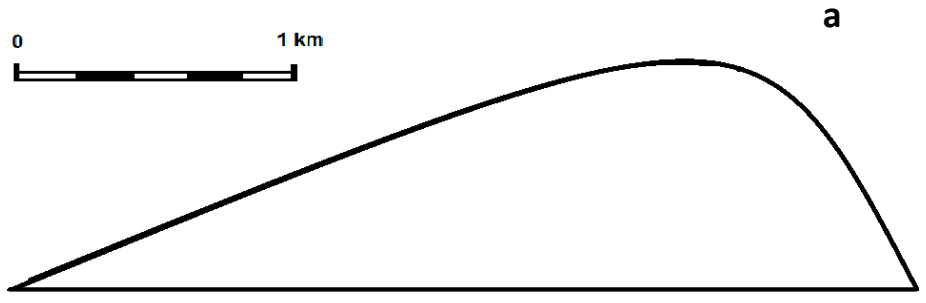

Depth of Detachment surface: $3.72 \mathrm{Km}$ Shortening: $24.64 \%$

Section area: $3.12 \mathrm{Km}^{2}$

Traverse name: (Dahqan a)

Fig. 7: a- Structural Profile for Traverse (1), b- Structural Profile for Traverse (2) of Dahqan Anticline.

\section{6- Fadhlya Anticline:}

This Fold extends in a (northwest-southeast) direction with a length of (10) $\mathrm{Km}$ and (5) $\mathrm{km}$ half wavelength. It is asymmetrical, verging towards southwest and single plunging where the southeastern end merges Bashiqa Anticline. Pila Spi is the oldest formation in the fold covered by Fat'ha and Injana formations which underline the alluvial deposits (Al-Azzawi, 2010). Figure 8, (a, b) shows the results of the applied method.

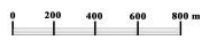

Scale 1:20000

b

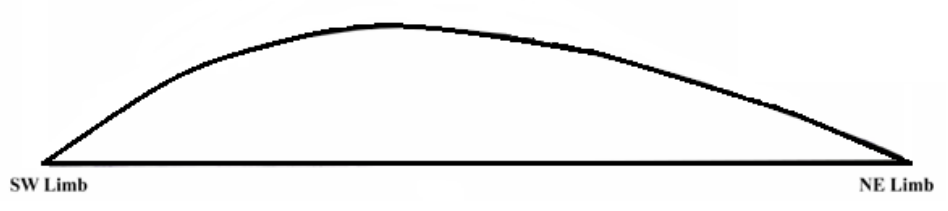

Depth of Detachment surface: $6.20 \mathrm{Km}$

Shortening: $12.85 \%$

Section area: $3.73 \mathrm{Km}^{2}$

Traverse name: (Fadhlya 1 )

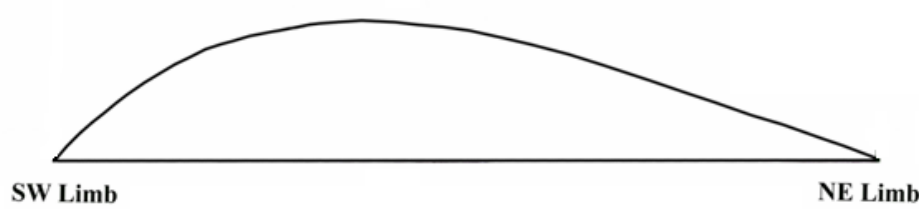

Depth of Detachment surface: $5.86 \mathrm{Km}$ Shortening: $12.95 \%$

Section area: $2.93 \mathrm{Km}^{2}$

Traverse name: (Fadhlya 2)

Fig. 8: a- Structural Profile for Traverse (1), b- Structural Profile for Traverse (2) of Fadhlya Anticline. 


\section{7- Permam dagh Anticline:}

Permam dagh is a double plunging anticline. It extends for about $15 \mathrm{Km}$ from the Greater Zab at the northwest to Koysanjaq at the southeast. The exposed stratigraphy of this anticline consisting of Pila Spi Fm. (Middle-Upper Eocene) which is considered as the carapace of this structure. Fat'ha Fm. (M. Miocene) overlies unconformably this formation and located at the limbs of the fold. It underlies Injana Fm (U. Miocene) in conformable manner which is mostly covered by alluvial deposits. Bakhtiari $\mathrm{Fm}$ is the youngest formation in the area (Al-Azzawi, 1982). Analysis of the transverse section is shown in (Fig. 10).

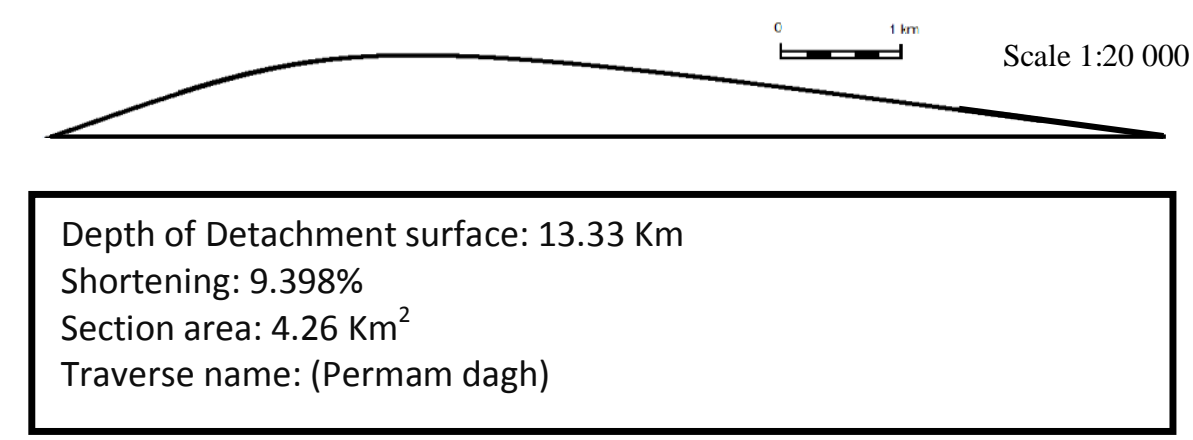

Fig. 10: Structural Profile for Traverse in the

Permam Dagh Anticline.

\section{8-Butma West Anticline:}

This fold is a double plunging anticline, extending in east-west direction and is asymmetrical verging towards the south following the Taurus Mountains. Euphrates Fm (L. Miocene) represents the core of the anticline and follows by Fat'ha and Injana formations (Al-Jawady, 1988). Transverse cross-section located at the central part is taken into consideration in the analysis and (Fig. 11) illustrates the determined parameters.

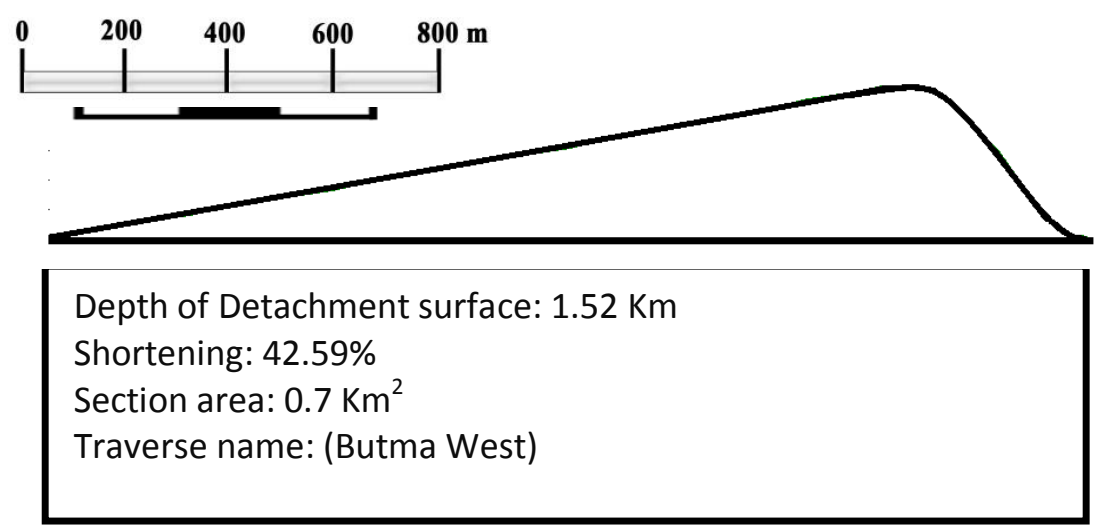

Fig. 11: Structural Profile for Traverse in the Butma West Anticline. 


\section{9-Ain Zala Anticline:}

Ain Zala Anticline is located in the northwest of Iraq. It is asymmetrical and extending for $19.5 \mathrm{Km}$ in east-west direction following the Taurus Mountains with $4.8 \mathrm{Km}$ width. The oldest exposed formation is Euphrates and it followed by Fat'ha and Injana formations (Al-Jawady, 1988). The structural profile drawn in the central region and the results of the analysis are displayed by (Fig. 12).

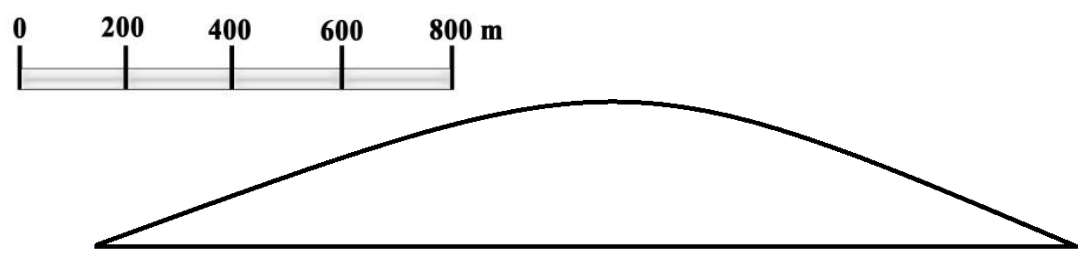

Depth of Detachment surface: $2 \mathrm{Km}$

Shortening: $29.26 \%$

Section area: $0.4 \mathrm{Km}^{2}$

Traverse name: (Ain Zala)

Fig. 12: Structural Profile for Traverse in the Ain Zala Anticline.

The other structural profiles for anticlines which are included in the current study have been constructed and calculated by previous studies such as Dohuk Anticline of AlKadum (2009), transverse sections for Bekhair and Qara Chauq Anticlines Al-Azzawi (2008) and two sections in the Brifka Anticline (Al-Sumaidaie, 2010).Table (1) illustrates the results of the present analysis.

Table 1: Represents Depth of DetaChment Surface and Shortening Ratios for some Studied Aniclines.

\begin{tabular}{|r|c|c|c|}
\hline No. & Fold Name & $\begin{array}{c}\text { Depth of Detachment } \\
\text { Surface Km }\end{array}$ & Shortening \% \\
\hline .1 & Brifka1 & 5.65 & 27.56 \\
\hline .2 & Brifka 2 & 5.20 & 34.39 \\
\hline .3 & Qara chauq & 6.88 & 18.71 \\
\hline .4 & Bekhair 3 & 7.76 & 26.15 \\
\hline .5 & Dohuk & 3.03 & 39.21 \\
\hline
\end{tabular}




\section{Discussion:}

The analysis has revealed that there are two types of detachment surfaces which are differentiated according to their depth. One of them is related to thickskinned tectonic and the other obeyed the thin-skinned one. These types are compared with what suggested by. Kley et al., (1999) which are described below:

\section{1- Thin-Skinned Tectonics and Thrust Belt:}

This type contains a shallow detachment faults within the sedimentary cover not more than $3 \mathrm{Km}$ in depth; the distinguished faults are long and continuous. Folds in this style have regular distances between them and the estimated shortening ratio is $40-70 \%$, (Fig. 13).

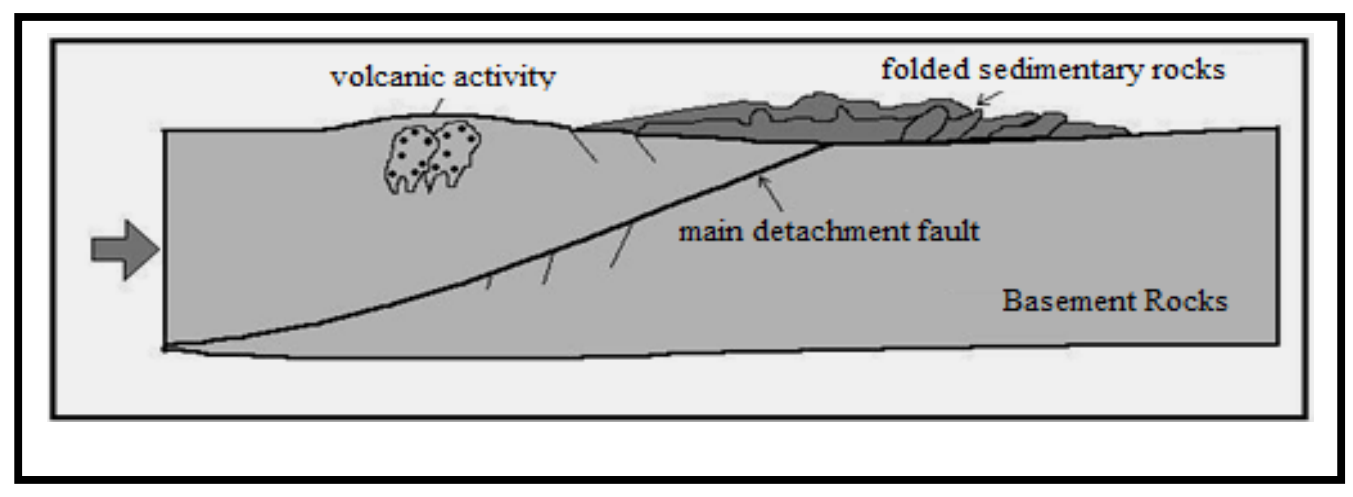

Fig. 13: Thin-Skinned Tectonics (From Kley et. al., 1999).

\section{2- Thick-Skinned Tectonics and Thrust Belt:}

This type contains a basic deep detachment fault. It's depth is about (10-20) $\mathrm{Km}$, and characterized by relatively short broad and irregular folds. It contains reactivated normal faults and the shortening ratio is about $20-35 \%$ (Fig. 14).

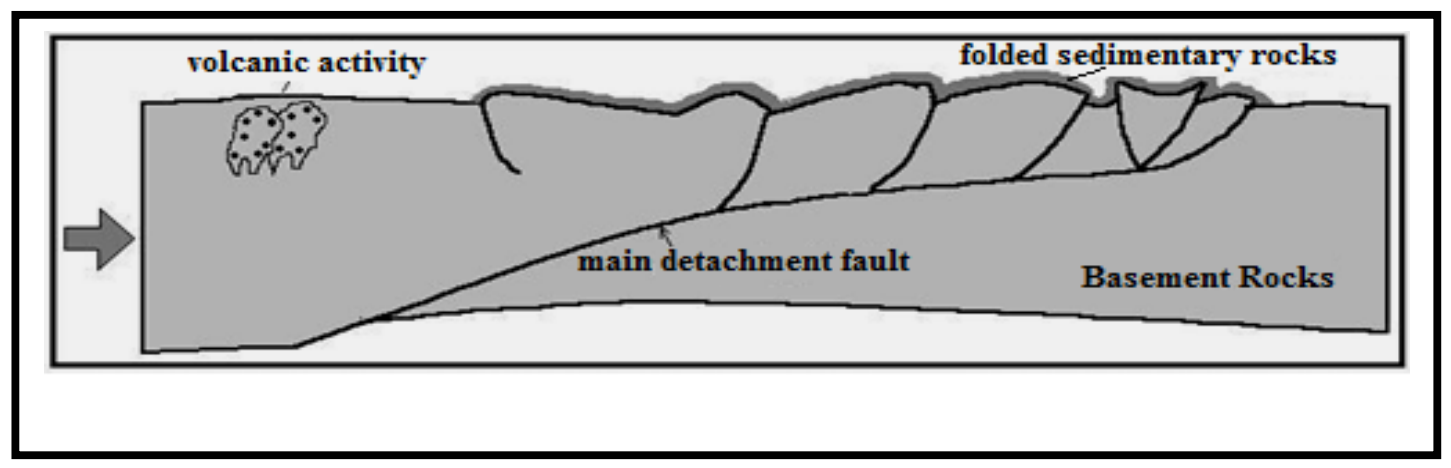

Fig. 14: Thick -Skinned Tectonics (From Kley et al., 1999) . 


\section{3- Foreland Basement Thrust Faults:}

These faults are characterized by the type of the entire continental crust deformation. The distances between these faults are wide, accompanying with broad wavelength folds and shortening ratio not exceeding $10 \%$.

The depth of detachment surface of each fold is almost constant with time progress where the amount of shortening increases with the orogenic progress. So that, the present study depends upon Kley et al., (1999) in classifying the detachment (thick or thin-skinned tectonics) of the studied anticlines. Subsequently, few folds are refered to thin-skinned which have $3 \mathrm{Km}$ depth of detachment surface or less and most of them have the characters of thick-skinned tectonics (Table 2).

These results lead to the conclusions that the detachment in our case is not continuously related to thick-skinned style, some of anticlines are related to thinskinned and must be separated in genesis from that of thick-skinned when they are represented on maps. Consequently, two maps and block diagram are built up separately. The first concerned with the thick-skinned folds which explain the behaviour of deep detached surface (Fig. 15: a, b ) and appears to be the dominant style in the forland belt. The second is reflected in the distribution of thin-skinned deformation which is acted within the sedimentary cover in the foreland area (Fig. 16: a, b).

Dahqan, Ain zala, Butma West, Duhok and part of Baikher have depths of detachment surface about $3 \mathrm{kms}$ or less. Therefore, they obey the thin-skinned tectonics (Table 2) and areas of these anticlines suffer shallow tectonic deformation within the sedimentary cover. Also no listric fault can be expected in these area. Subsequntly, these areas are considered as locally deformed and not relats to the regional deformation of thick-skinned tectonics. Analyses of the other anticlines reveals that depths of detachment surface are ranging from (5.18 - 13.33) $\mathrm{km}$. These results make these anticline, related to thick-skinned. In other words these areas are subjected to deep-seated fault (Listric faults). These faults reach the basement due to thier depth of about $(5.18-13.33) \mathrm{km}$ and the basement depth is about (9-12) km, in comparism with Al-Brifkani (2008), and Aqrawi et.al., (2010). this means that the depth of detachment surface in these areas coincide with the basement depth. Some of the listric faults may break up the basement like permam dagh Anticline (Table 2), some are tangential and other have not been reached.

According to the depths of detachment surface, amount of shortening is also differentiated into two categories. The first which a companied with thick-skinned tectonic and the others with the thin-skinned. Subsequently, two maps and blocks are produced with three dimensional block diagrams (Fig. 17: a, b and 18: a, b).

Kley et al., (1999) and Al-Sumaidaie (2010) suggested that the amount of shortening is inversely proportional with the depth of detachment surface. This is because in constant stress the thin-skinned suffer more stress than thick-skinned type. Thin-skinned have 40-70\% shortening whereas thick-skinned owing 20-35\% (Kley et al., 1999). In general this concept is confirned in this work. But the 
proportion does not work in details in comparison with all of the studied cases. The present authors believe that there are another factors controlling this relation and do not appear in this study.

Table 2: Results of Each Detachment Surface and the Shortening Amount of Anticlines.

\begin{tabular}{|c|c|c|c|c|c|c|c|c|c|c|}
\hline $\begin{array}{c}\text { Name of } \\
\text { Anticlines }\end{array}$ & $\begin{array}{c}\text { L0 } \\
(\mathrm{km})\end{array}$ & $\begin{array}{c}\mathbf{L c} \\
(\mathrm{km})\end{array}$ & $\begin{array}{c}\text { SC } \\
(\mathrm{km})\end{array}$ & $\begin{array}{c}\text { Asr } \\
(\mathbf{k m 2})\end{array}$ & $\begin{array}{c}\text { Depth of } \\
\text { detachment } \\
\text { h }(\mathrm{km})\end{array}$ & $\begin{array}{c}\mathbf{A f} \\
(\mathrm{km} 2)\end{array}$ & $\begin{array}{c}\mathbf{I e} \\
(\mathrm{km})\end{array}$ & $\begin{array}{c}\text { Ta } \\
(\mathrm{km} 2)\end{array}$ & $\begin{array}{c}\mathbf{A R} \\
(\mathrm{km} 2)\end{array}$ & Shortening \\
\hline Berat 1 & 9.12 & 11 & 1.88 & 13.83 & 7.35 & 67.09 & 0.5 & 4.56 & 18.39 & 27.41 \\
\hline Berat 2 & 9.4 & 11.2 & 1.8 & 15.56 & 8.64 & 81.25 & 0.58 & 5.45 & 21.01 & 25.85 \\
\hline Dahqan 1 & 3.2 & 3.68 & 0.48 & 1.57 & 3.27 & 10.48 & 0.48 & 1.53 & 3.10 & 29.64 \\
\hline Dahqan 2 & 3.4 & 3.8 & 0.4 & 1.49 & 3.72 & 12.67 & 0.48 & 1.63 & 3.12 & 24.64 \\
\hline Aqra 1 & 6.3 & 7.48 & 1.18 & 7.16 & 6.06 & 38.23 & 0.7 & 4.41 & 11.57 & 30.26 \\
\hline Aqra 2 & 6.2 & 7.6 & 1.4 & 7.25 & 5.18 & 32.14 & 0.7 & 4.34 & 11.59 & 36.08 \\
\hline Aqra 3 & 6 & 7.2 & 1.2 & 6.30 & 5.25 & 31.52 & 0.7 & 4.2 & 10.50 & 33.32 \\
\hline $\begin{array}{l}\text { Pemum } \\
\text { dagh }\end{array}$ & 8 & 8.32 & 0.32 & 4.26 & 13.33 & 106.67 & 0.72 & 5.76 & 10.02 & 9.39 \\
\hline $\begin{array}{l}\text { Shaikhan } \\
1\end{array}$ & 6.2 & 7.2 & 1 & 6.45 & 6.45 & 39.99 & 0.18 & 1.11 & 7.56 & 18.91 \\
\hline $\begin{array}{l}\text { Shaikhan } \\
2\end{array}$ & 8 & 9.32 & 1.32 & 10.2 & 7.72 & 61.81 & 0.18 & 1.44 & 11.64 & 18.82 \\
\hline Fadhlya 1 & 4.68 & 5.04 & 0.36 & 2.23 & 6.20 & 29.02 & 0.32 & 1.49 & 3.73 & 12.85 \\
\hline Fadhlya 2 & 3.87 & 4.16 & 0.29 & 1.7 & 5.86 & 22.68 & 0.32 & 1.23 & 2.93 & 12.95 \\
\hline Brifka1 & 7.12 & 8.2 & 1.08 & 6.10 & 5.65 & 40.23 & 0.7 & 4.98 & 11.08 & 27.55 \\
\hline Brifka 2 & 7.52 & 8.8 & 1.28 & 6.65 & 5.20 & 39.10 & 0.9 & 6.76 & 13.42 & 34.32 \\
\hline $\begin{array}{l}\text { Qra } \\
\text { chauq }\end{array}$ & 5.92 & 6.77 & 0.85 & 5.85 & 6.88 & 40.77 & 0.3 & 1.77 & 7.62 & 18.70 \\
\hline Bekhair 3 & 8.76 & 10.26 & 1.5 & 11.63 & 7.75 & 67.97 & 0.7 & 6.13 & 17.77 & 26.14 \\
\hline Dohuk & 3.4 & 4.06 & 0.66 & 2 & 3.03 & 10.30 & 0.6 & 2.04 & 4.04 & 39.21 \\
\hline Bekhair 1 & 3.62 & 4.4 & 0.78 & 2.58 & 3.31 & 12.01 & 0.52 & 1.88 & 4.47 & 37.21 \\
\hline Bekhair 2 & 5.48 & 6.1 & 0.62 & 4.00 & 6.45 & 35.39 & 0.5 & 2.74 & 6.74 & 19.05 \\
\hline $\begin{array}{l}\text { Buta } \\
\text { West }\end{array}$ & 2.2 & 2.66 & 0.46 & 0.7 & 1.52 & 3.34 & 0.33 & 0.72 & 1.42 & 42.59 \\
\hline Ain Zala & 1.7 & 1.9 & 0.2 & 0.4 & 2 & 3.4 & 0.35 & 0.59 & 0.99 & 29.26 \\
\hline
\end{tabular}


Detachment Surface Morphology and Shortening Distribution................

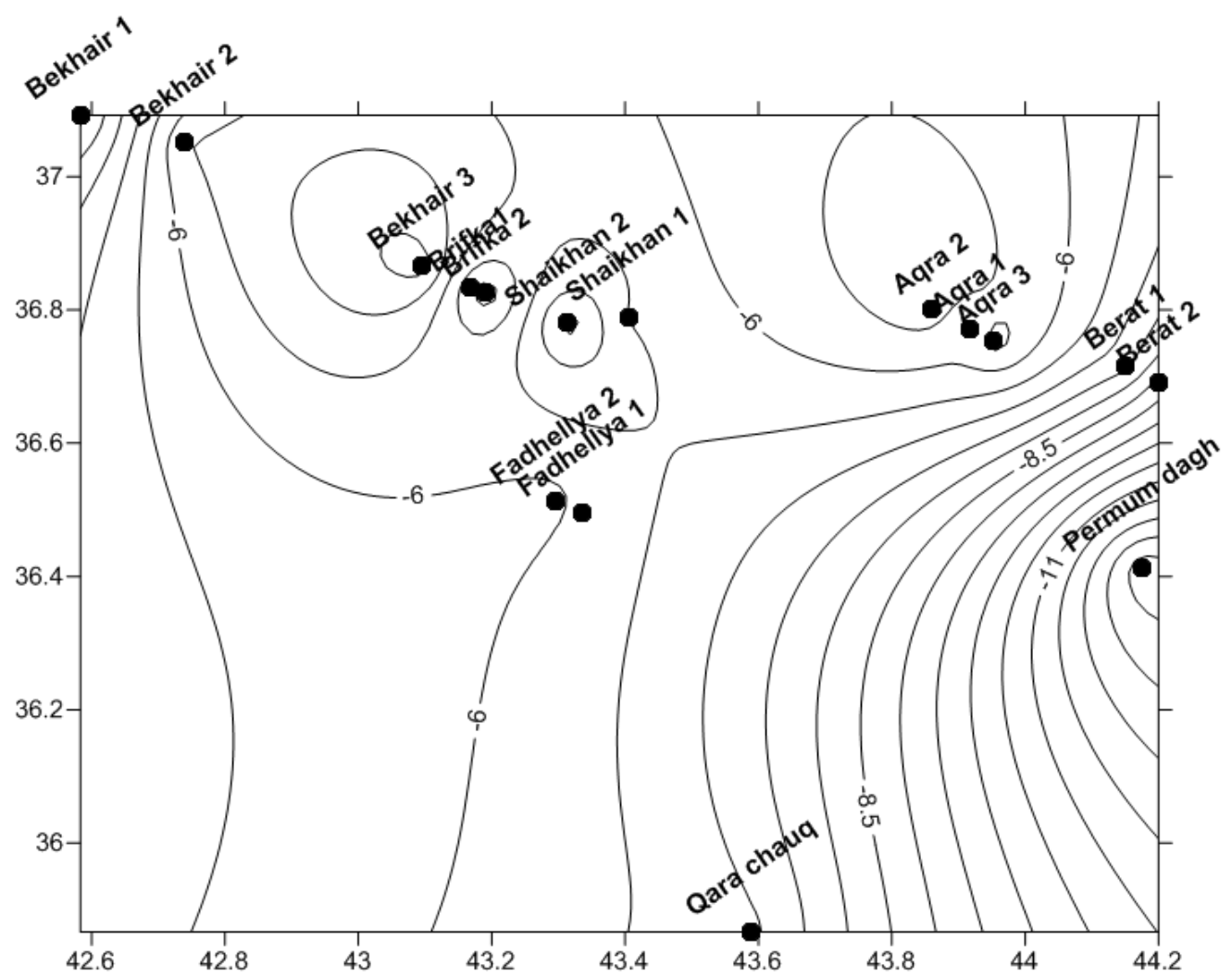

Fig. 15: a- The Contour Map for Depth of Detachment Surface Mornhologv for Thick-Skinned.

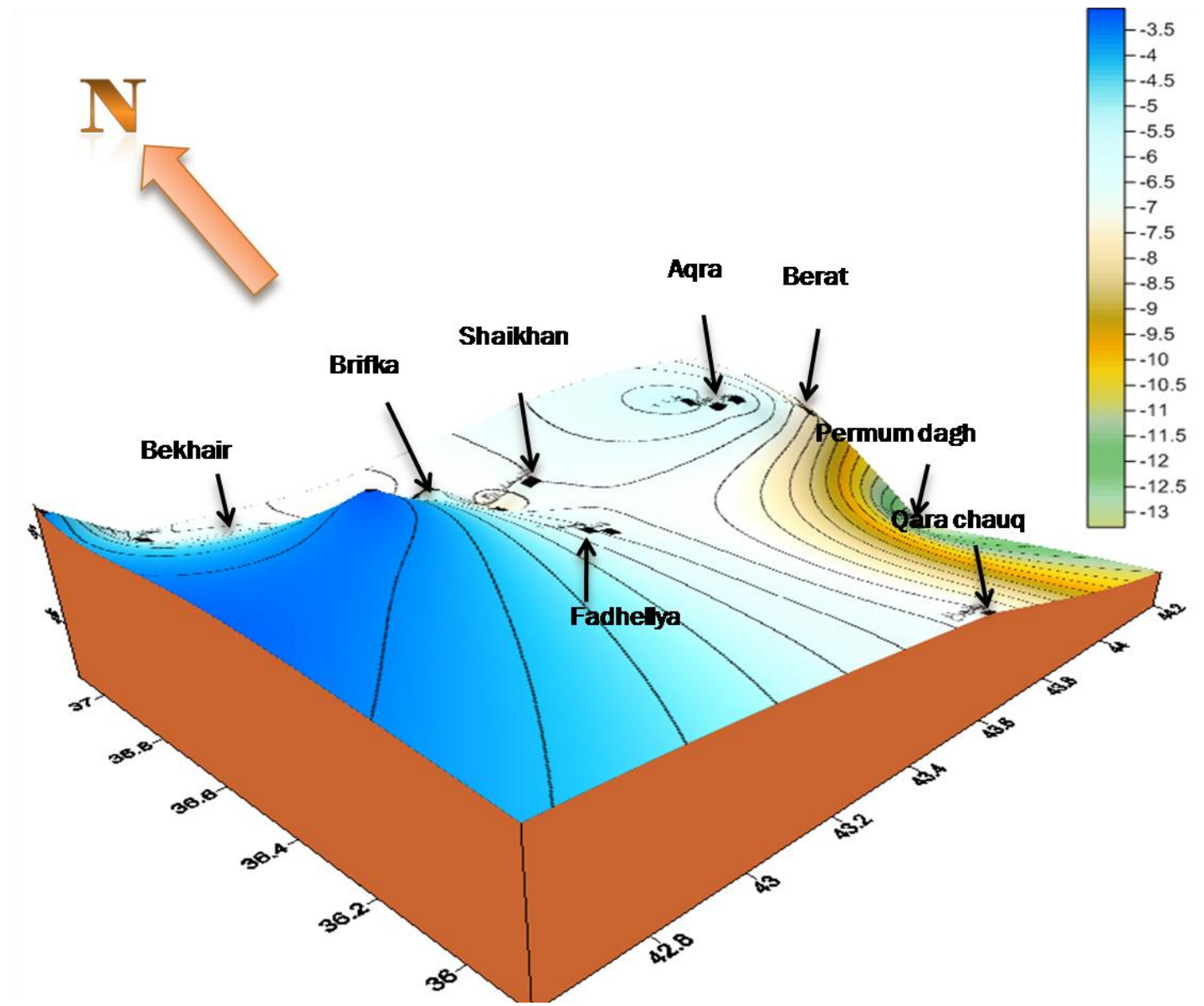

Fig.15: b- The Block Diagram for Depth of Detachment Surface Morphology for Thick-Skinned. 


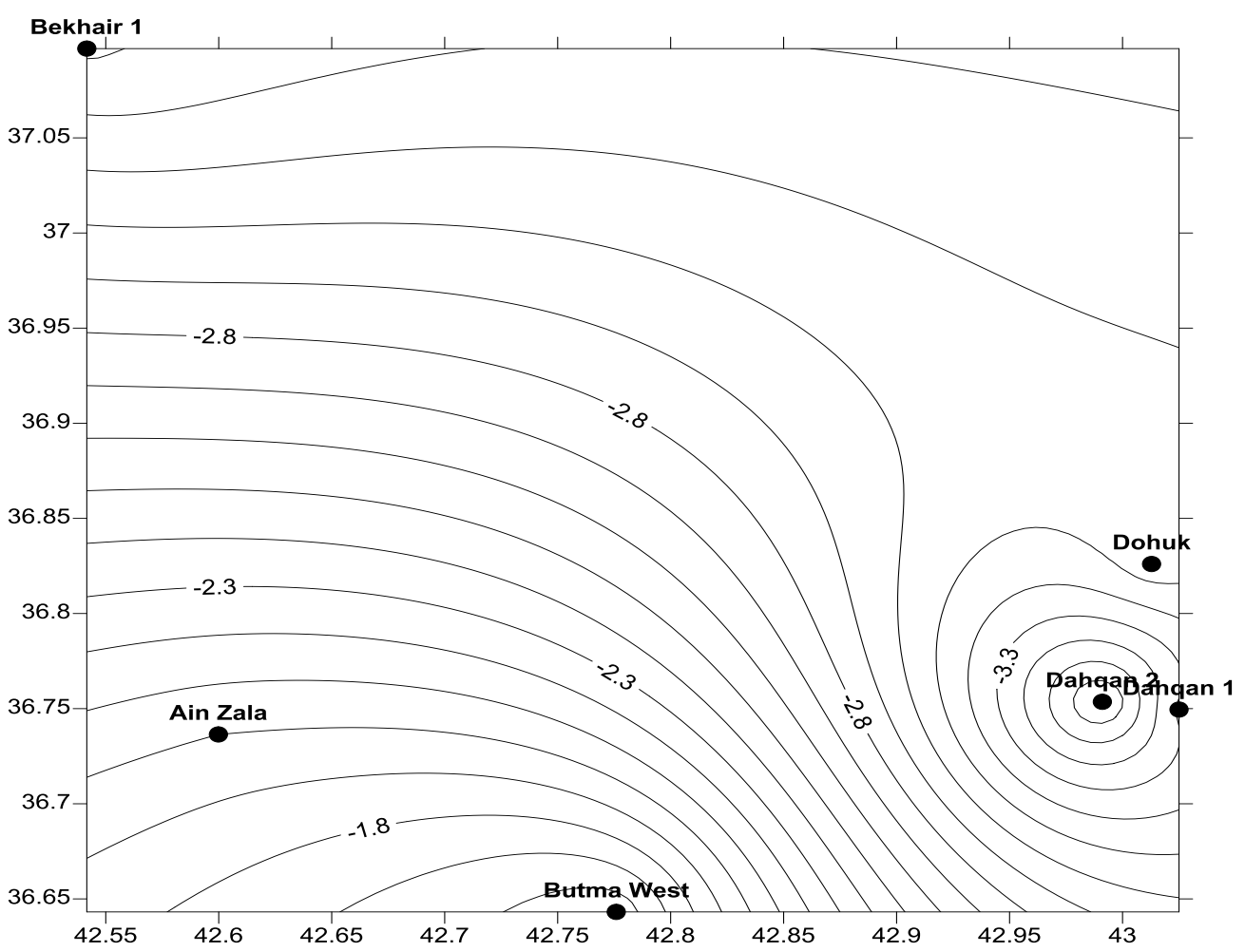

Fig. 16: a- The Contour Map for Depth of Detachment Surface Morphology for Thin-skinned.

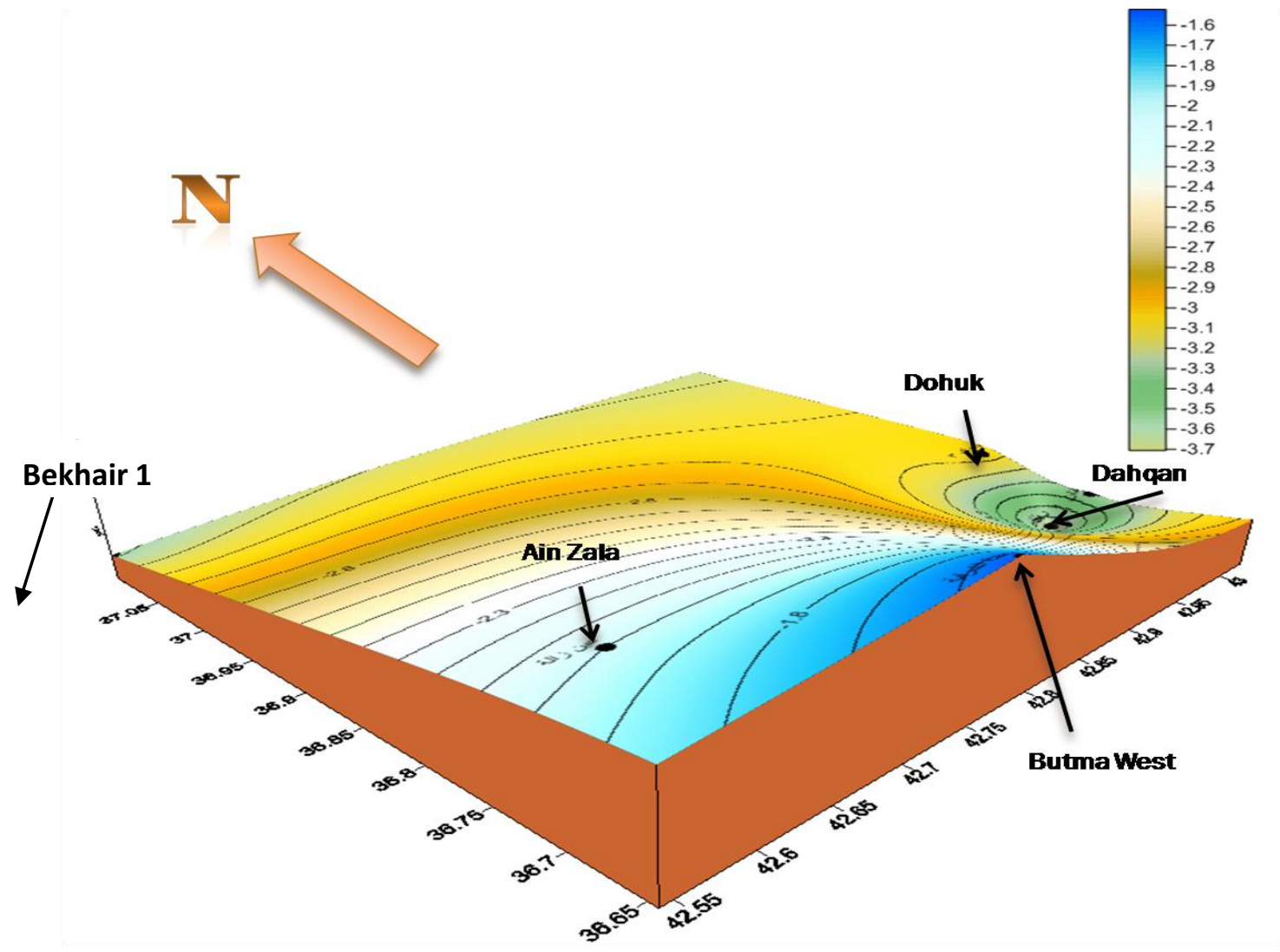

Fig. 16: b- The Block Diagram for Depth of Detachment Surface Morphology for Thin-skinned. 

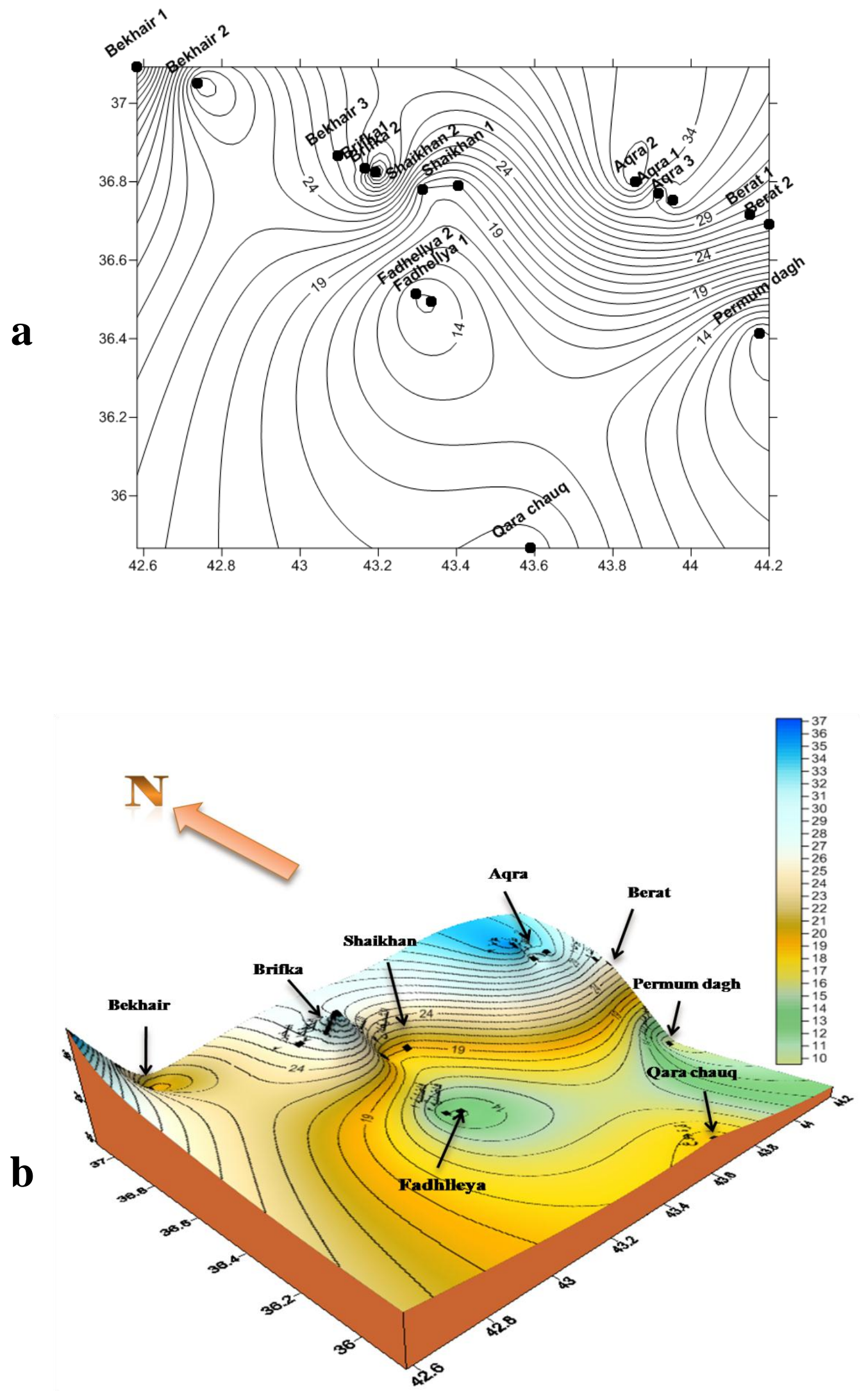

Fig. 17: a-The contour map for Shortening amount morphology for Thick-skinned.

b-The Block Diagram for Shortening Amount Morphology for Thick-skinned. 
a

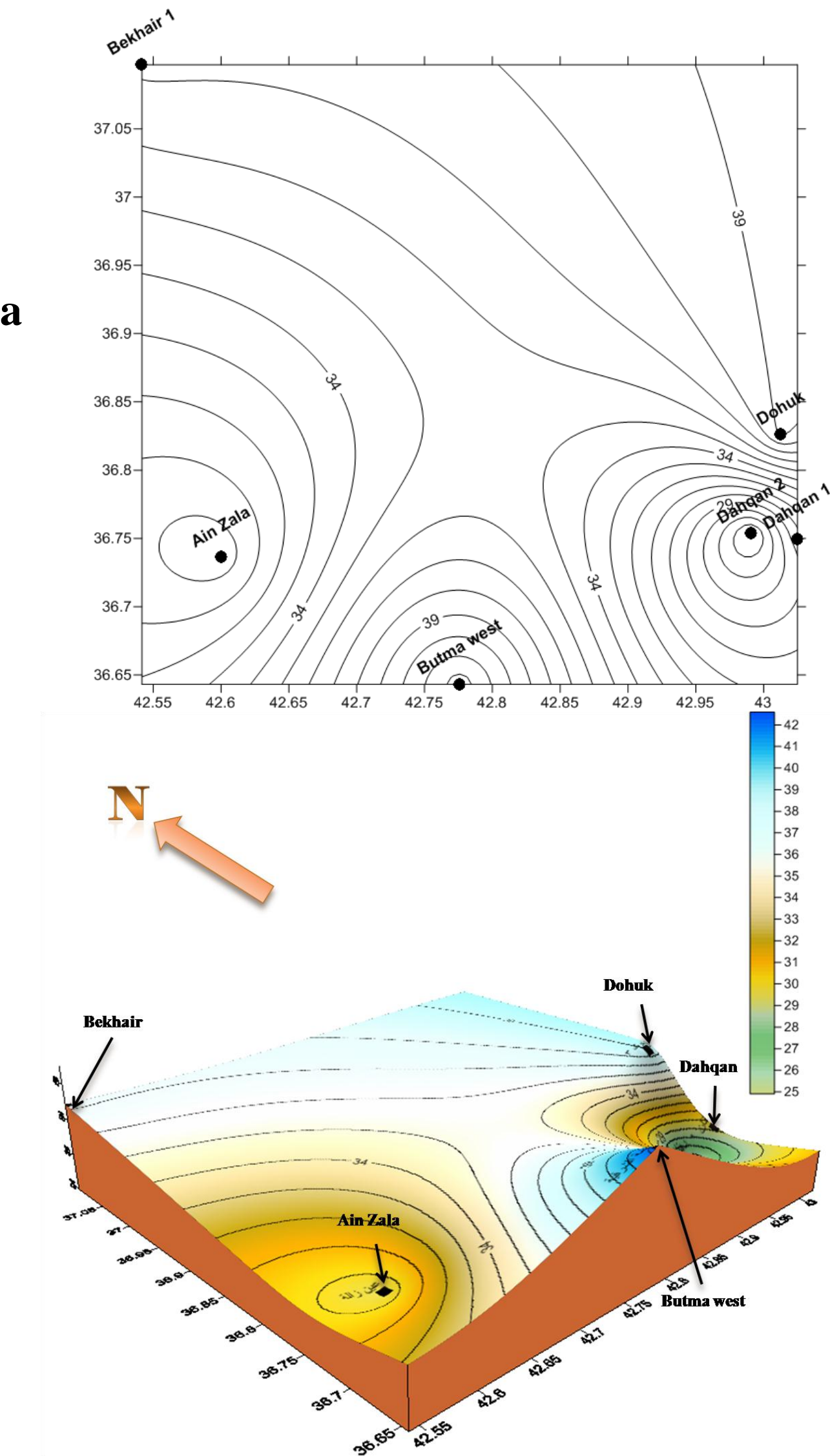

Fig. 18: a-The Contour Map for Shortening Amount Morphology for Thin-skinned.

b-The Block Diagram for Sshortening Amount Morphology for Thin-skinned. 


\section{CONCLUSIONS}

Analysis of the evolving parameters, percentage of shortening and depth of detachment surface, leads the authors to the following conclusions:

1-Detachment surface in the foreland belt can be classified into two types according to which kind of deformation that the anticline belong. They are thick-skinned or thin-skinned tectonics.

2- In thick-skinned, depth of detachment, surface generally increases towards east, with an abnormal cases such as in Aqra Anticline. While in the western part, depth of the detachment increases towords the north with maximum amount at Bekhair Anticline (Bekhair 3).

3- Thin-skinned deformation appears in Ain Zala, Butma West, Duhok and Dahqan anticlines and some parts of Bekhair Anticline.

4- The above two points indicate that the detachment in the foreland area is not completely belong to the thick-skinned style. Some folds have shallow detachment surface within the sedimentary cover, so they obey the thin-skinned.

5 - The percentage of local shortening also obeys the same concept. In thickskinned, this percentage generally increass towards north and northeast, with an abnormal cases such as Permum Dagh Anticlines. This percentage increasesin the area from Permam Dagh to the north whereas it becomes shallow to the south and it appears minimum in Qara Chauq Anticline. Whereas the thinskinned gives same interpretation as in the detachment surface.

6- The results of this analysis are compared with Shali (1990), Aqrawi et al, (2010) and they show compatible coincidence.

7- It is not necessary for the anticline to the deformed in the same style of tectonics. Anticline like Bekhair obeys thick-skinned in places (Barushki Yekmalah) and thin-skinned in other like Zakho and Sumeel. This is because this anticline is extremely long and various factors controlled in its formation.

8-In general the depth of detachment surface is inversely proportion with the shortening ratio. There are some exceptions which indicate that there are another factors controlling the depth of detachment surface them.

\section{REFERENCES}

Al-Azzawi, N. K., 1982. Comparative Study of the Sectonic Styles of Folds in Three Areas in the Simple Folded Zone of Iraq, Unpublished M.Sc. Thesis, University of Mosul, Iraq.

Al-Azzawi, N. K., 2003. The Structural Development of Fold Shape in the Foreland Belt of Iraq. And Its Tectonic Implications, Unpublished Ph. D Thesis, University. of Mosul, Iraq. 
Al-Azzawi, N. K., 2008. Local Shortening of Folds and Detachment Surface Depth with Examples from the Foreland Belt of Iraq. Iraqi Journal. Earth science., vol.8, No.1. pp 34-43.

Al-Azzawi, A. Gh., 2010. The Structural and Tectonic Analysis of Bashiqa and AL-Fadhlya Anticlines- Northern Iraq, Unpublished. M.Sc. thesis, University of Mosul, Iraq.

Al-Hamdani, R. K. H., 1992. Stratigraphy and Structure of the Southeastern Part of Berat Anticline (Bekhme Area). Unpublished. M.Sc. Thesis, University of Mosul, Iraq.

Al-Brifkani, M. J. N., 2008. Structural and Tectonic Analysis of the Northern Thrust Zone. Unpublished Ph. D Thesis, University. of Mosul, Iraq.

Al-hubiti, S. T., 2008. Tectonic Style Changes Along Bekhair Anticline AxisNorthern Iraq, Unpublished M.Sc. Thesis, University of Mosul, Iraq.

Al-Jawady, Z. Y., 1988. Morphotectonics of (Ain Zala - Raffan - Butma) Region, Unpublished M.Sc. Thesis, University of Baghdad, Iraq.

AlKadum, , N. A., 2009. Structure of Dohuk Anticline- Northern Iraq its Tectonic Implications, Unpublished M.Sc. Thesis, University of Basra, Iraq.

Al-khatony, S. E., 2009. The Structural Analysis and Tectonic Interpretation of Shaikhan Anticline - Northern Iraq, Unpublished M.Sc. Thesis, University of Mosul, Iraq.

Al-Sammarrai, H. M., 1990. Geology and Structure of Faidah Area (Dahqan Anticline), Unpublished M.Sc. Thesis, University of Mosul, Iraq.

Al-Shali, R. A., 1992. Balancing Cross Sections from the Simple Folded Zone of Iraq, Unpublished M.Sc. Thesis, University of Mosul, Iraq.

Al-Sumaidaie, M. A., 2010. Structural and Tectonic Study of Brifka Anticline Northern Iraq, Unpublished M.Sc. Thesis, University of Mosul, Iraq.

Aqrawi A. A. M., Goff J.C., Horbury A. D., Sadooni F. N., 2010. The Petroleum Geology of Iraq. Scientific Press Limited, United Kingdom, 424 p.

Billings, M., 1972. Structural Geology, third edition, Prentice- Hall Inc, 606 p.

Kley, J., Monaldi, C.R., Salfity, J. A., (1999). Along-Strike Segmentation of the

Andean Foreland: Causes and Consequences, Tectonophysics, Vol. 301, pp.75 - 94.

Maroof, N. Z., 1983. Structural and Geological Study of Aqra Area, Unpublished

M.Sc. Thesis, University of Baghdad, Iraq.

Ragan, D. M., 1985. Structural Geology: An Introduction to Geometrical Techniques; John Wiley and Sons. Inc., New York. 393p.

Ramsay, J. G., and Huber, M. I., 1987. The Techniques of Modern Structural Geology: Vol. 2, Folds and Fractures, Academic Press, London, UK,700 p. Suppe, J., 1985. Principle of Structure Geology. Prentice-Hall, Inc, New Jersey, $537 \mathrm{p}$. 